\title{
From the Unity of Nature to Sustainability Science: Ideas and Practice
}

\author{
Robert W. Kates \\ CID Working Paper No. 218 \\ March 2011
}

(C) Copyright 2011 Robert W. Kates and the President and Fellows of Harvard College
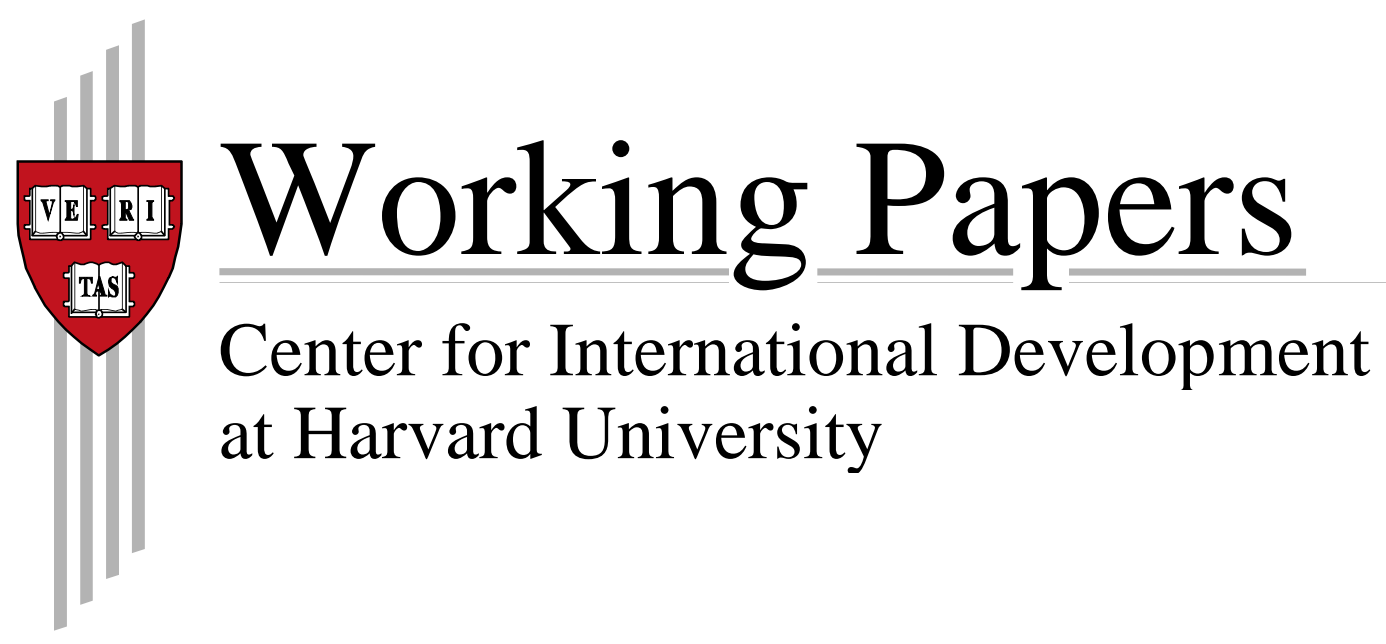


\title{
From the Unity of Nature to Sustainability Science: \\ Ideas and Practice
}

\author{
Robert W. Kates
}

\begin{abstract}
The ideas of sustainability science are at least two centuries old; the practice is but a decade. This paper reviews some of those key ideas beginning with Humboldt and the unity of nature, and goes on to discuss just what is sustainability science. For its current practice, the author discusses three major tasks of sustainability science: fundamental research on use-directed problems; nurture of the next generations of sustainability scientists; and moving knowledge into action. The author illustrates each of these with some recent initiatives.
\end{abstract}

Keywords: sustainability science, sustainability science research, sustainable development, sustainability education, environment and development, sustainability solutions

JEL subject codes: Q01, Q56, Q57 


\section{Citation, Context, and Program Acknowledgements}

This paper may be cited as:

Kates, Robert W. 2011. "From the Unity of Nature to Sustainability Science: Ideas and Practice.” CID Working Paper No. 218. Center for International Development, Harvard University. Cambridge, MA: Harvard University, March 2011.

It is available at http://www.hks.harvard.edu/centers/cid/publications/faculty-workingpapers/cid-working-paper-no.-218. Comments are welcome and should be directed to the author at rwkates@gmail.com.

Robert Kates trained as a geographer and taught geography for many years at Clark University in Worcester, Massachusetts, USA. He also participated in interdisciplinary programs addressing both environment and development at the University of Dar as Salaam in Tanzania, at Clark University, and at the World Hunger Program at Brown University in Providence, Rhode Island, USA. Kates now serves as a Senior Research Fellow at Harvard, co-convener of the Steering Group for the Initiative on Science and Technology for Sustainability, and Presidential Professor of Sustainability Science at the University of Maine. Kates served as co-chair for the National Academy of Sciences' report, Our Common Journey: A Transition toward Sustainability. His current research is on community resilience, adaptation to climate change, and long-term trends, values, attitudes, and beliefs affecting a sustainability transition. Much of his writing can be found on http://rwkates.org. He is a member of the National Academy of Sciences, the American Academy of Arts and Sciences, and Academia Europaea. In 1991 he was awarded the National Medal of Science for his work on hunger, environment, and natural hazards. He now lives and works as an independent scholar in Maine.

The Sustainability Science Program at Harvard's Center for International Development harnesses the University's strengths to promote the design of institutions, policies, and practices that support sustainable development. The Program addresses the challenge of sustainable development by: advancing scientific understanding of human-environment systems; improving linkages between research and policy communities; and building capacity for linking knowledge with action to promote sustainability. The Program supports major initiatives in policy-relevant research, faculty research, training of students and fellows, teaching, and outreach. See http://www.hks.harvard.edu/centers/cid/programs/sustsci.

The CID Working Papers have not undergone formal review and approval. Copyright belongs to the author. Papers may be downloaded for personal use only. 


\section{Table of Contents}

1. Ideas of Sustainability Science.......................................................................................................... 1

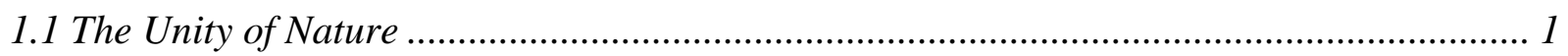

1.2 Nature Modified by Human Action .............................................................................. 1

1.3 Nature Linked to Human Development........................................................................ 2

1.3.1 NAS-NRC Board on Sustainable Development 1995-99 …….................................. 2

1.3.2 Fribergh Workshop on Sustainability Science........................................................... 2

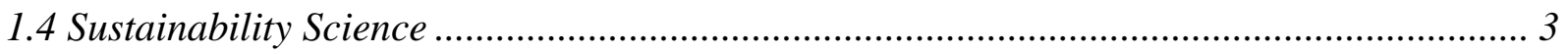

2. Major Tasks of Sustainability Science ................................................................................................... 5

2.1 Fundamental Research on Use-inspired Problems ........................................................ 5

2.1.1 Core Research Questions and Themes.................................................................... 5

2.1.2 Elaborating Human-environment (H-E) Systems ...................................................... 6

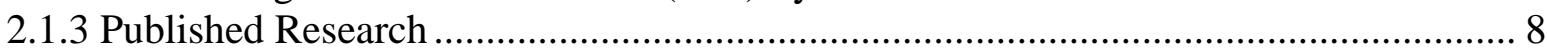

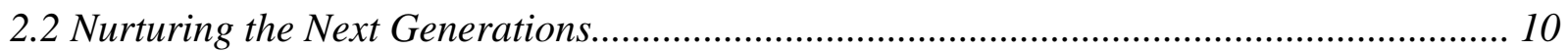

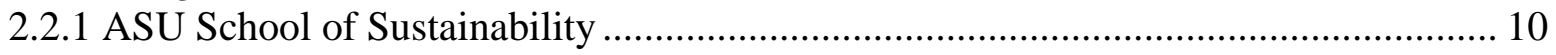

2.2.2 Readings in Sustainability Science and Technology .................................................. 11

2.2.3 Sustainability Science Distributed Graduate Seminar ................................................... 11

2.3 Moving Knowledge into Action............................................................................... 12

2.3.1 Knowledge into Action Challenges ...................................................................... 12

2.3.2 Acting on What We Already Know..................................................................... 13

2.3.3 Maine Sustainability Solutions Initiative ................................................................... 13

3. From the Unity of Nature to Sustainability Science ....................................................................... 14

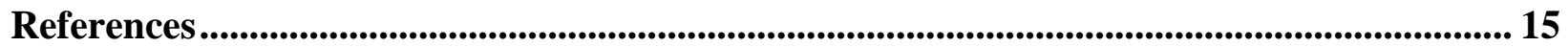


The ideas of sustainability science are at least two centuries old; the practice is but a decade. . This paper reviews some of those key ideas beginning with Humboldt and the unity of nature and goes on to discuss just what is sustainability science. For its current practice, I discuss three major tasks of sustainability science: fundamental research on use-directed problems; nurture of the next generations of sustainability scientists; and moving knowledge into action. I illustrate each of these with some recent initiatives.

\section{Ideas of Sustainability Science}

I have selected some of the major ideas that contributed to the development of sustainability science from a much larger set, beginning first with Humboldt's dream of understanding the unity of nature. This was followed by George Perkins Marsh's vision of nature as modified by human action. Then much later, the International Union for the Conservation of Nature (IUCN) linked nature and human development, which led to the World Commission on Environment and Development, and culminated in the NAS report of Our Common Journey and the call for a sustainability science.

\subsection{The Unity of Nature}

Let me begin with Humboldt's dream. Humboldt, 29 years old, set out his dream in 1799 in a letter to friends as he awaits his sailing from Spain to Venezuela and the beginning of his five year exploration of the Orinoco River and the Andes Mountains. He describes his dream as follows:

In a few hours we sail round Cape Finisterre. I shall collect plants and fossils and make astronomic observations. But that's not the main purpose of my expedition-I shall try to find out how the forces of nature interact upon one another and how the geographic environment influences plant and animal life. In other words, I must find out about the unity of nature. (Alexander von Humboldt as quoted in Nicolson 1995, p. ix)

He would pursue the dream until the final posthumous publication of Volume 5 of the Kosmos in 1862. But his dream was not to be shared widely, for by then, the Academy had discovered another more powerful approach to understanding nature, but not its unity. To pursue this new approach of reductionism, specialization increased, disciplines were born, and graduate degrees were invented.

\subsection{Nature Modified by Human Action}

Beyond the unity of nature, the second great idea was that of a nature modified by human action. George Perkins Marsh, the remarkable Vermonter, wrote Man and Nature in 1862 and revised it as Earth Modified by Human Nature in 1874 (Marsh 1965 [1862, 1874]) documenting for the first time the destructive impacts of human activity on the biosphere. A more detailed examination of human activity took place in 1956 (Thomas 1956), but 30 years later a systematic review moved beyond modification and found the earth transformed (Turner II et al. 1990). Along the way, Vernadsky had integrated human knowledge with the biosphere in a noosphere (Vernadsky 1926), and Rachel Carson has initiated the modern environmental movement with her Silent Spring (Carson 1962). 


\subsection{Nature Linked to Human Development}

In an earth already transformed by human action the next great idea was to link nature or the environment to development, particularly human development. Thus, sustainable development was born, emerging in the early 80s from scientific perspectives on the interdependence of society and environment led by the International Union for Conservation of Nature in the World Conservation Strategy (1980). It gained considerable political attention through the publication by the Brundtland-led World Commission on Environment and Development (1983-87) report: Our Common Future (WCED 1987) and the subsequent United Nations Conference on Environment and Development held in Rio de Janeiro in 1992. There were no scientists on the World Commission and little science present in Rio. Ten years later at the Johannesburg World Summit, there was some scientific presence, in part, because work on sustainability science had already begun.

\subsubsection{NAS-NRC Board on Sustainable Development 1995-99}

Thus I want to turn to the most recent of the emergent ideas of sustainability science, the work of the National Academy of Sciences Board on Sustainable Development. In 1995 the National Academy of Sciences created a Board on Sustainable Development. I served as vice-chair along with Bill Clark, and we began a five year effort to reconnect science and technology to sustainable development. We sought to make the concept of sustainable development manageable and measurable by focusing on a minimal sustainability transition over two relatively foreseeable generations. Using one of the major social science scientific findings, that of the demographic transition, we envisioned a world population of around 9 billion in fifty years. To decide what constituted a sustainability transition we chose three normative goals that had emerged at the top of priority-setting negotiations of international conferences and summits: meeting the human needs of the 9 billion, while preserving the life support systems of the planet, and reducing hunger and poverty. To do so we argued for acting on what we already know and creating a sustainability science for what we needed to know.

\subsubsection{Friibergh Workshop on Sustainability Science}

But having finished our report and presented it along with other efforts to a meeting of the World Academies of Sciences (Interacademy Panel on International Issues 2000) which embraced the notion of a sustainability science, we also realized that there was much to learn on how to do sustainability science. So with assistance from Sweden, we convened a small international workshop to identify the core questions and methodologies of sustainability science (Kates et al. 2001), and this was followed by a series of regional meetings in Africa, Asia, Latin America, and North America (International Council for Science (ICSU) 2002).

Our discussions at Friibergh and in the subsequent regional meetings revealed profound differences in problems and perspectives between scientists based in developed countries focusing primarily on global issues and those in developing countries focusing primarily on local issues, and separated by a variety of economic, digital, and capacity divides (Figure 1). Scientists in the north worried about the effects of affluence and consumption, climate changes and its causes, and undertook theory-driven research. Scientists in the south worried about the effects of poverty and underconsumption, the impacts of climate change, and undertook action-driven research. Scientists in the north took for granted broadband internet access and many sources of 
funding. Scientists in the south tried to cope with interrupted electricity, worked at multiple jobs to support themselves, and had few sources of funding.

Such differences notwithstanding, the workshops also reflected broad agreement that science and technology have an enormous potential to make important contributions to a sustainability transition. Realizing that potential, however, will require that serious efforts be made to promote science for sustainability. It will have to be more than the status quo, such as simply renaming work we are already doing or claiming that specific work in either environmental science or development studies is sustainability science. And sustainability science is not just an extension of existing research agendas (e.g., that of Earth System Science) or action agendas (e.g., that of climate change) to include goals of sustainability.

Figure 1. Differences in problems and perspectives in developed and developing countries. Scientists based in developed countries focus primarily on global issues, worry about consumption, climate changes and its causes, and undertake theory-driven research with needed tools and funds. Scientists based in developing countries focus primarily on local issues, worry about poverty and underconsumption, the impacts of climate change, and undertake actiondriven research, always short of facilities and funding (based on Figure 1 in Kates et al. 2001).

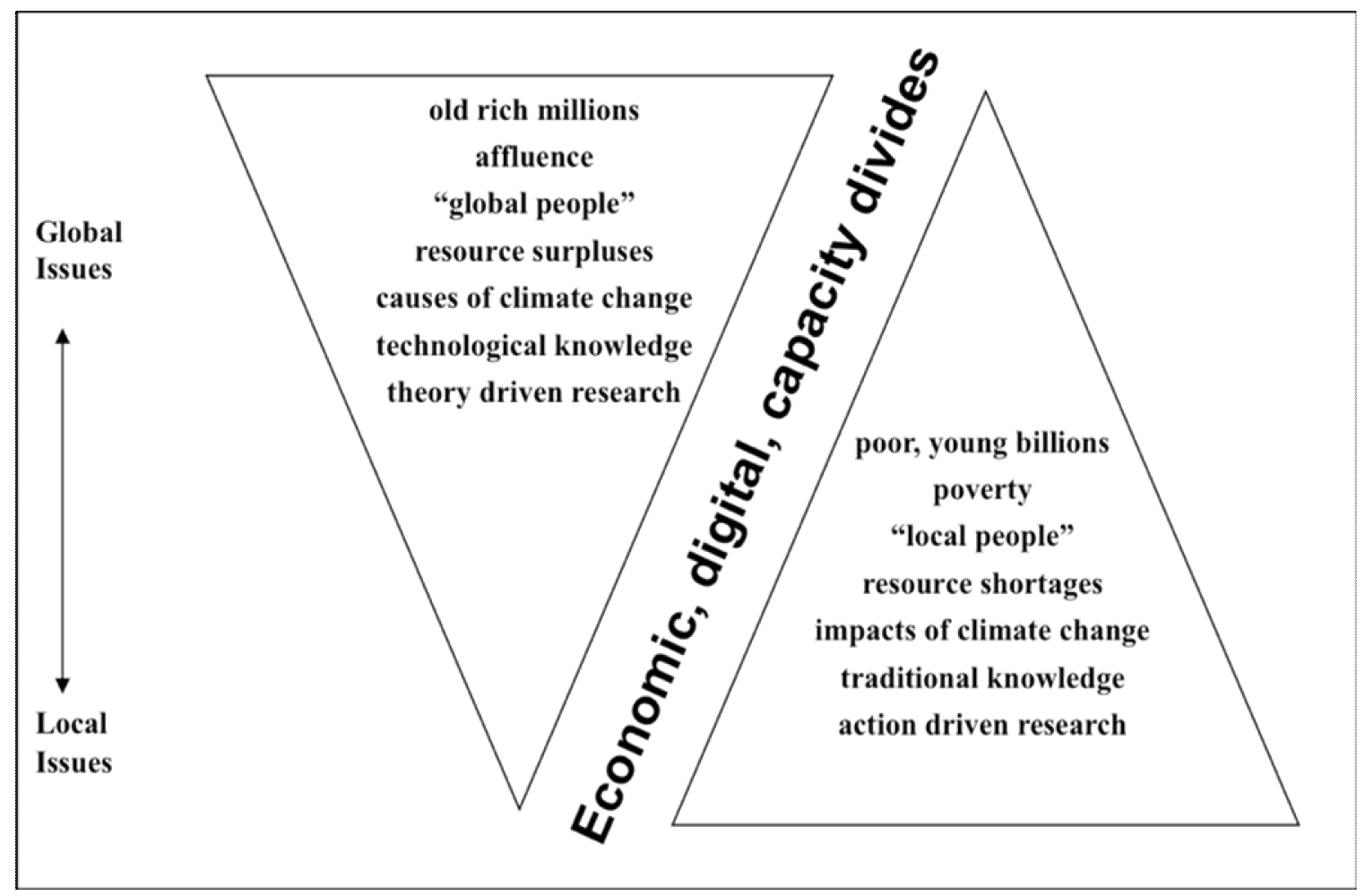

\subsection{Sustainability Science}

Rather, science and technology for sustainability should be essentially integrative, working to integrate the natural, social, and engineering sciences; seeking to bridge the communities 
engaged in promoting environmental conservation, human health, and economic development; and bringing together the worlds of knowledge and action.

Our discussions also revealed agreement that much of science and technology for sustainability will need to be regional and place-based, focused at intermediate scales where multiple stresses intersect to threaten or degrade human-environment systems. In a sense, sustainable development differs in every place as human needs and life support systems vary, and hunger and poverty is smaller or larger. It is in these places that the complexity of coupled human-environmental systems is more readily comprehensible, where innovation and management happen, and where significant transitions toward sustainability have often begun.

We also agreed in our workshops that sustainability science addresses such fundamental science questions as scale, non-linear processes and complexity, and the unity of nature and society. How to relate the universal with the particular, the whole with its parts, the global and the local? Can component parts explain the properties of larger systems, and are such properties knowable? How do the earth, its living biota, and our human species work?

Thus our global conversations concluded that science and technology for sustainability will need to be simultaneously fundamental and applied. It should address cutting-edge questions regarding nature-society dynamics, while recognizing the concurrent needs to address sustainability concerns in problem-solving mode and to apply what we already know in sciencebased action programs. Donald Stokes' (1997) quadrant model of scientific research is instructive with his two by two view of research contrasting the quest for fundamental understanding with the quest for utility (Figure 2). In the model, there is the Neils Bohr quadrant high in fundamental understanding and little utility and that of Thomas Edison in the pure applied quadrant. In contrast, the sustainability science quadrant of use-inspired fundamental research is exemplified by the discoveries of Louis Pasteur.

Figure 2. Quadrant model of scientific research. Donald Stokes' (1997) two by two view of research contrasts the quest for fundamental understanding with the quest for utility.

\section{Quadrant Model of Scientific Research}

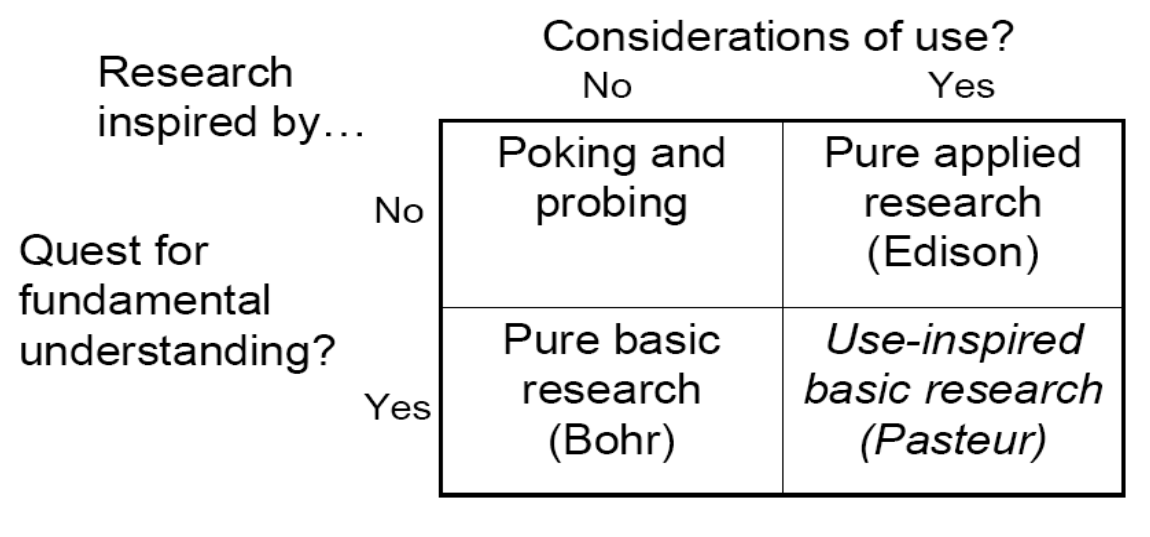

(redrawn from Stokes, 1997) 
For a succinct definition of sustainability science, I prefer that of the Proceedings of the National Academy of Sciences (PNAS 2010) as: “....an emerging field of research dealing with the interactions between natural and social systems, and with how those interactions affect the challenge of sustainability: meeting the needs of present and future generations while substantially reducing poverty and conserving the planet's life support systems." Variants of this definition are widely accepted, but as sustainability science spreads around the world, different emphases emerged, as in Europe (Jäger 2009, European Commission 2009), Japan (Komiyama et al. 2010), or the U.S. (Clark 2007, Matson 2009).

\section{Major Tasks of Sustainability Science}

Over its first decade there have been three major tasks for sustainability science. The first is to fulfill the Pasteur quadrant (Figure 2) and do fundamental research on use-directed problems. For a science that sees itself active over the generations, the second is to nurture the next generations of sustainability scientists. And third, as our new knowledge accumulates we need to move it into action. I will illustrate the progress currently being made for each task with three examples.

\subsection{Fundamental Research on Use-inspired Problems}

Over this last decade, core fundamental research questions and themes have been identified. Central to these has been the study of coupled human-environment systems. Existing models for many of the components of human-environment systems have been evaluated for their suitability for integrated sustainability assessment. And a growing body of fundamental research on useinspired problems has been published.

\subsubsection{Core Research Questions and Themes}

There have been two major attempts to put together core research questions for sustainability science. In the Friibergh workshop of 2000 (Kates et al. 2001) seven core questions were identified, and these survived the set of regional meetings in Africa, Asia, Latin America, and North America that followed (International Council for Science 2002). Last year, at the initiative of the U.S. National Science Foundation, a conference on "Towards a Science of Sustainability" was convened at the Airlie Center. There were twice as many conferees at Airlie as in the original Friibergh workshop, but unlike that workshop, most were from the United States. The conference identified six sets of major thematic research. Table 1 compares these questions and themes (Clark and Levin 2010). Four of these core questions and research themes are almost identical in both efforts, but were often expanded in the Airlie version. Three of the Friibergh core questions (in italics) were not specifically singled out at the Airlie Conference, while two new themes (in italics) of trade-offs between natural and human systems and rigorous evaluation of sustainability trajectories were added.

Research questions are now better defined with these two rounds of overlapping questions and themes, but of the original core set of research questions, major progress has been made only in long-term trends and vulnerability or resilience. Selected progress has been made in limits and boundaries, but primarily climate; in incentive structures, primarily for common resources or conservation; in monitoring and reporting, primarily from space; and in integrated activities, primarily interdisciplinary. The two new themes on $\mathrm{H}-\mathrm{E}$ tradeoffs and sustainability trajectories seem well justified. In both analyses, a basic need emerges for better theory and models to bridge the gap between those expert in modeling approaches but not in $\mathrm{H}-\mathrm{E}$ systems and those empirical 
scientists knowledgeable about H-E systems but not modeling complexity. Only in climate modeling has better theory and models been partly achieved.

Table 1: Sustainability Science Research Questions and Themes. The Friibergh international workshop of 2000 (Kates et al. 2001) identified seven core research questions for sustainability science. A decade later, a U.S. conference on "Towards a Science of Sustainability" selected six major research themes. Those that differ between the efforts are in italics.

\section{Sustainability Science Research Questions and Themes}

Friibergh, 2000

(Kates et al., 2001)

Core Questions
Airlie House, 2009

(Clark and Levin, 2010) Major Themes
Integrative H-E models

Long-term trends

Vulnerability or resilience

Incentive structures

Limits or boundaries

Monitoring and reporting
H-E theory and models

Long-term trends \& transitions

H-E systems adaptability

Guidance of H-E systems

$H$-E tradeoffs

Evaluation of sustainability trajectories

Better integrated activities

\subsubsection{Elaborating Human-environment (H-E) Systems}

At the heart of sustainability science are closely coupled human-environment systems, more easily described with box and arrow models than detailed with numbers and equations. I use these all the time, although I suspect that box and arrow diagrams are more useful to their authors than prospective viewers. Nevertheless, to illustrate a few points let me borrow two recent boxes and arrows diagrams (Figures 3, 4) from B. L. Turner II (2010). The basic overview of interacting H-E systems have been used for many years (e.g., Burton, Kates, and White 1976), although labeled variously as nature-society, or socio-ecological, as well as human-environment. But much effort over the past decade has focused on detailing interactions (wavy line), exogenous flows from other coupled systems, and in elaborating the human and environmental subsystems such as in Figure 4.

Figure 3. The coupled human-environment system. The basic overview of interacting H-E systems have been labeled variously as nature-society, socio-ecological, or human-environment and contain a human subsystem, environmental subsystem, and other external systems that impact these. Source: (Turner 2010). 


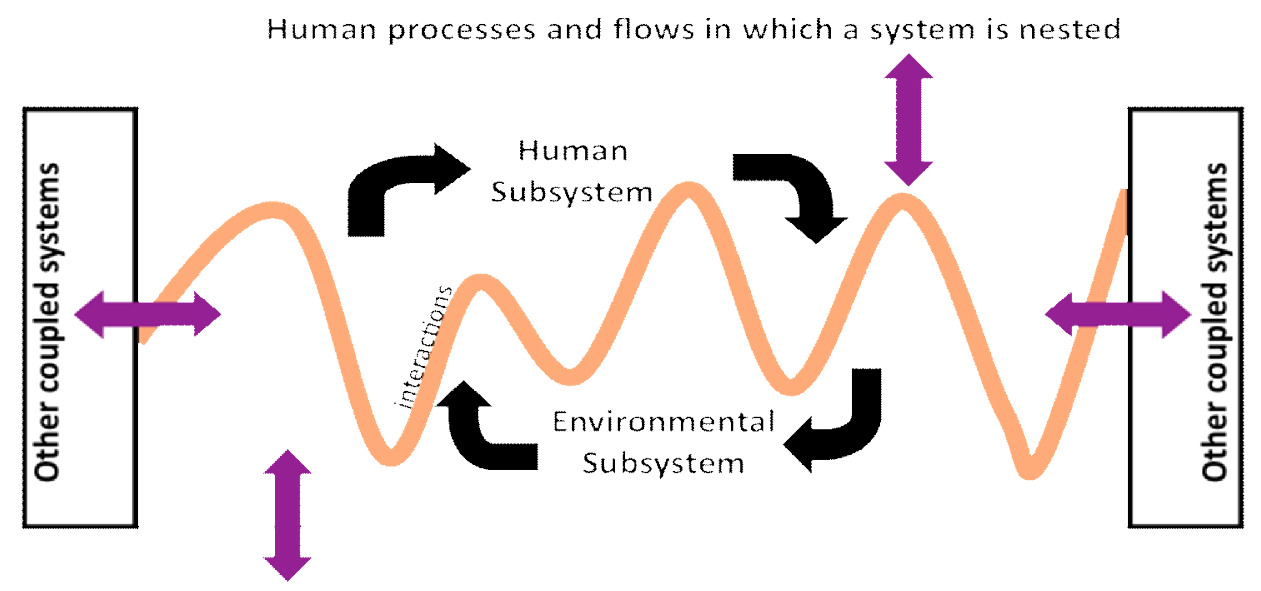

Environmental processes and flows in which a system is nested

Fig. 3: The coupled human-environment system overview

There has been an emerging consensus that important elements of human subsystems are population, technology, governance, and economy as shown in Figure 4. But these are still studied primarily as separate elements and introduced into models, usually as external inputs or scenarios. A major addition to the environmental subsystem has been ecosystem services (Daily et al. 1997) and is widely used as the major output of the environmental subsystem. Judging from the literature of the last decade, much of coupled H-E study focuses on the environmental subsystem with less attention to the human subsystem (see 2.1.3).

Figure 4. Inner-workings of coupled human-environment systems. Each of the subsystems have been expanded with the human subsystem including population, technology, governance, and economy and the environmental subsystem including a biogeophysical earth system, ecosystems, and ecosystem services. Source: (Turner 2010).

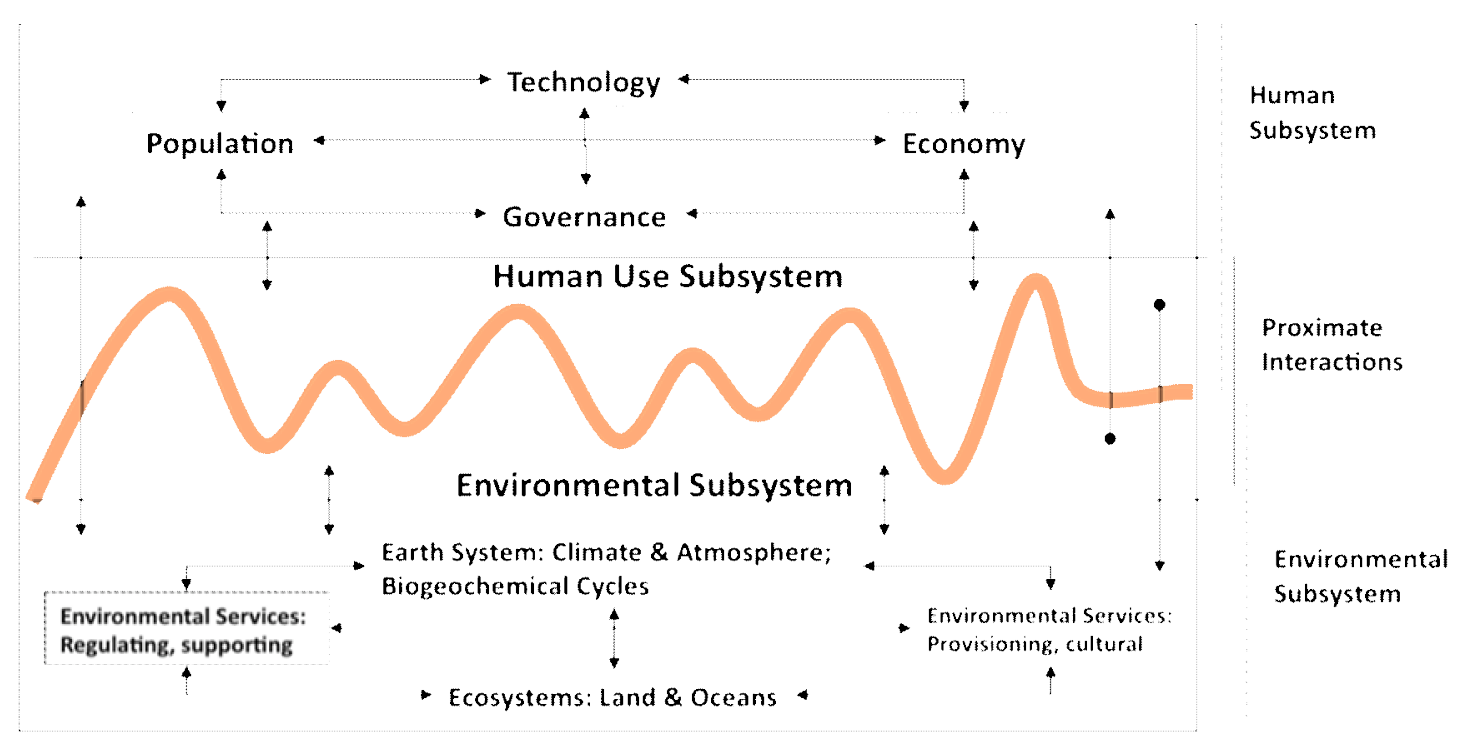

Fig. 4: Inner-workings of Coupled Human-Environment Systems 
Modeling tools already exist for many of the components of human-environment systems described above. A major European effort (2005-2008) on Methods and Tools for Integrated Sustainability Assessment (MATISSE) (Lotze-Campen 2008) focused on methods and tools for integrated sustainability assessment. This included comparative evaluations of dozens of available biophysical, socio-economic, and integrated models, as shown in the Table 2 by their acronyms. Overall, MATISSE concluded that integrated sustainability assessment was in its infancy (Lotze-Campen 2008).

Table 2. Models evaluated for integrated sustainability assessment by MATISSE project. Models are listed by acronym. For full titles see (Lotze-Campen 2008). Source of table: (LotzeCampen 2007).

\begin{tabular}{|c|c|}
\hline CATEGORY & MODELS (Examples) \\
\hline \multicolumn{2}{|l|}{ Biophysical models } \\
\hline Climate & $\begin{array}{l}\text { GCM (HadCM, ECHAM): } \\
\text { EMIC (CLIMBER, MAGICC/SCENGEN) }\end{array}$ \\
\hline Hydrology & WaterGAP, SWIM, IRM-ABM \\
\hline Biogeochemistry & LPJ, VECODE, 4C, WOFOST, ACCESS \\
\hline \multicolumn{2}{|l|}{\begin{tabular}{|l|}
$\begin{array}{l}\text { Socio-economic } \\
\text { models }\end{array}$ \\
\end{tabular}} \\
\hline General economy & $\begin{array}{l}\text { GE (GTAP, WorldScan, GEM-CCGT, GEM-E3, SNI-AGE): } \\
\text { Macroeconometric (E3ME, NEMESIS, QUEST-II, GINFORS) }\end{array}$ \\
\hline Partial economy sectors & $\begin{array}{l}\text { Energy (POLES, PRIMES, MARKAL); Agriculture (WATSIM, } \\
\text { IMPACT, CAPRI, RAUMIS); Transport (TREMOVE) }\end{array}$ \\
\hline Demography & PHOENIX, IIASA Population Project \\
\hline Public health & MIASMA, PHSF, TARGET \\
\hline \multicolumn{2}{|l|}{ Integrated models } \\
\hline Land use change & FARM, AgLU, MAgPIE, CLUE, SFARMOD, CORMAS \\
\hline $\begin{array}{l}\text { Qualitative systems } \\
\text { analysis }\end{array}$ & SYNDROMES, QSA-SCENE \\
\hline Integrated assessment & $\begin{array}{l}\text { IMAGE, ICLIPS, FUND, MIND, DEMETER, RICE-FEEM, GENIE, } \\
\text { IMPACT-WATER }\end{array}$ \\
\hline $\begin{array}{l}\text { Scenario building and } \\
\text { planning }\end{array}$ & QUEST, POLESTAR, THRESHOLD-21, FAIR \\
\hline
\end{tabular}

\subsubsection{Published Research}

The growing sets of sustainability science research results have many new sources for publication, including traditional journals such as Global Environmental Change or Proceedings of the National Academy of Sciences (PNAS), new journals such as Sustainability Science, internet journals such as Ecology and Society, review volumes such as the Annual Review of Environment and Resources, and more popular written pieces as in Environment.

During the last decade the Proceedings of the National Academy of Sciences (PNAS) established a Sustainability Science section in which public access is readily available (PNAS 2010). Many 
of the best of research results appear there. (Only about 1 in 5 submissions to PNAS are accepted.) From 2003 through 2010 there have been 232 articles in that section, many of them in special features, which characterize the range of current sustainability science research. These include marine reserves, ecosystem services, poverty, health, governance, food security, climate change, and land use change.

A more detailed analysis of sustainability science research examined the titles of the 232 PNAS papers for the years 2003-2010 listed under Sustainability Science (Table 3). The papers were classified from their titles under 16 topics, using nine describing human needs and seven describing life support systems, as used in a Reader (Kates 2010). Where titles seemed to contain multiple topics, they were allotted to all of the topics; thus, the number of topics is larger than the number of papers. Twelve were unclassifiable by title.

Table 3: Sustainability Science research by topic as reflected in titles to PNAS articles. The titles of the 232 PNAS papers for the years 2003-2010 listed under Sustainability Science (PNAS 2010) were classified from under 16 topics, using nine describing human needs and seven describing life support systems, as used in a Reader (Kates 2010).

\begin{tabular}{|l|l|l|}
\hline \multicolumn{1}{|c|}{ Human Well-being } & $\begin{array}{c}\text { Topics } \\
\#\end{array}$ & $\begin{array}{l}\text { Topics } \\
\%\end{array}$ \\
\hline Population & 3 & 1 \\
\hline Health \& Well-being & 13 & 5 \\
\hline Poverty/Affluence & 11 & 4 \\
\hline Habitation \& Transportation & 7 & 2 \\
\hline Peace \& Security & 0 & 0 \\
\hline Energy \& Materials & 20 & 7 \\
\hline Food \& Fibre & 44 & 16 \\
\hline Water \& Sanitation & 2 & 1 \\
\hline Disasters & 8 & 3 \\
\hline & 108 & 38 \\
\hline \multicolumn{1}{|c|}{ Life Support Systems } & & \\
\hline Climate \& Stratospheric Ozone & 60 & 21 \\
\hline Land & 35 & 12 \\
\hline Atmosphere & 6 & 2 \\
\hline Water & 9 & 3 \\
\hline Oceans & 20 & 7 \\
\hline Biodiversity & 25 & 9 \\
\hline Ecosystem Services & 18 & 6 \\
\hline Total & 173 & 62 \\
\hline Grand total & 281 & 100 \\
\hline PNAS Papers 2003-2010 & 232 & \\
\hline
\end{tabular}

From these data, the first eight years of Sustainability Science research seems to have been devoted primarily to environment (life support systems 62\%) rather than development (human needs $32 \%$ ) and concentrated in only six topics: climate (21\%), agriculture (16\%), land use, primarily forests (12\%), biodiversity $(9 \%)$, energy \& materials $(7 \%)$, oceans \& fisheries $(7 \%)$. 
Using this analysis, there is a clear bias in sustainability science towards environmental science. The varied fields of development sciences that include health and human development, economic and social development, governance, and the multitude of technologies that make development possible are still underrepresented. A second bias is that despite considerable developing country science involvement, the current agenda still seems to reflect the priorities of first-world, primarily environmental scientists. A similar bias is to the global despite the emphasis in sustainability science on regional and place-based studies.

\subsection{Nurturing the Next Generations}

Sustainable development is a century-long goal and the best sustainability scientists are probably still unborn. Thus, the second of our tasks is that of nurturing the next generation of sustainability scientists. Here are three current examples: educational opportunity at Arizona State University, the just-completed Readings in Sustainability Science, and the just-concluded distributed graduate seminar in sustainability science.

\subsubsection{ASU School of Sustainability}

Since 2002 President Michael Crow has been refiguring Arizona State University (ASU) into a new type of American university, featuring, among many things, an emphasis on sustainability. There is a sustainability effort throughout its various schools with the intent that sustainability principles be introduced eventually to all of its 71,000 students. But there is also a specific School of Sustainability, which had enrolled, as of September 2010, 581 undergraduate majors and 84 graduate students, 58 of whom are $\mathrm{PhD}$ candidates. A minor in sustainability is available to all undergraduates at ASU.

The School of Sustainability represents one major approach to sustainability science educationthe creation of new sustainability science degrees. At least ten $\mathrm{PhD}$ degree programs and many more Master's programs are available around the world, either in sustainability science or sustainable development. It is much too early to know how such degrees will be received in academia as entry to graduate work or for academic employment. Thus, an alternate approach is to create teaching programs with sustainability nomenclature within existing disciplines, programs, or centers. At ASU, for example, undergraduate concentrations and degree programs are available in the Business School, the Institute of Design and the Arts, the Engineering School, the Law School, and the College of Liberal Arts and Sciences. But as the environmental disciplines or programs are often the hosts, this may add to the environmental bias discussed above.

To help students bridge the gap between textbooks and careers or graduate education, ASU encourages and supports numerous opportunities for undergraduates to participate in real world internships, workshops, and service, and all students are required to take and successfully complete an applied/capstone learning, or research experience. Further, the School of Sustainability partners with community businesses and organizations to provide undergraduate and graduate internships. An internship coordinator helps students match their interests and capabilities with outside internship hosts and monitors these to ensure that the internship experience counts as credit toward fulfilling degree requirements (Buizer 2011). 


\subsubsection{Readings in Sustainability Science and Technology}

As educational opportunities continue to increase in sustainability science, there is need for new sets of educational materials. A major effort over four years are the Readings in Sustainability Science and Technology, available as Harvard Center for International Development Working Paper 213 (Kates 2010), as well as available on the internet. For teachers of advanced undergraduate students and beginning graduate students, it suggests a three-part architecture for courses organized around three major domains of sustainability science.

The first presents an overview of sustainable development that begins with the history of sustainable development and the dual goals of sustainable development- the promotion of human development and well-being, while protecting the earth's life support systems. Readings are provided for the current status, long-term trends, and impacts of nine essentials for human well-being and seven essential life support systems. It concludes with describing the interactions of human society and the life support systems as these have been sketched-simply, realistically, and imaginatively.

The second part of the Reader focuses on what, why, and how to do sustainability science and technology. For what to do in sustainability science, it examines three essential qualities of the emerging science: its use or needs orientation, focus on human-environment systems, and goal of integrated understanding. For why to do sustainability science, it considers normative values and the science of identifying and analyzing values and attitudes. For how to do sustainability science, it examines the current practice of the science, the analyses undertaken, and the distinctive methods and models used.

The Reader ends with linking knowledge systems and action, using examples of both global and local solutions to the needs of human well-being and the earth's life support systems. It specifically identifies three critical needs that constitute grand challenges: poverty, climate change, and peace and security.

In all, there are some 93 readings to choose from for course material, supported by a mini-text of 60 pages to place them in context. In its current form, the Reader has been reviewed extensively and many suggestions for additional topics incorporated. But as an electronic reader it can be frequently updated and users are requested to send commentary and suggestions for new or replacement readings to: 〈sustsci_reader@hks.harvard.edu〉

\subsubsection{Sustainability Science Distributed Graduate Seminar}

In the fall semester of 2010 seven universities (Arizona State, Cornell, Florida International, Harvard, Minnesota, the National University of Mexico (UNAM), and Princeton) took part in an internet-based distributed graduate seminar, attended by 120 students overall. The lecturers were, for the most part, authors of draft chapters from a book to be completed in 2011: Sustainability Science: An Introduction, which served as the primary readings for the course and were supported by readings from the Reader described above. For each session students at a particular school took the initiative in commentary that was later also opened to all. Course materials and video recordings of the sessions can be currently downloaded from their website (https://groups.nceas.ucsb.edu/sustainability-science). Overall, student and faculty viewed the course as an exciting success, especially after early technological difficulties were overcome. 


\subsection{Moving Knowledge into Action}

Perhaps the most challenging task of sustainability science is moving knowledge into action. I will begin with tracking the global and local agenda of needed action, report on major opportunities that act on what we already know how to do, and conclude with an exciting statewide effort, focusing on solutions to sustainability problems.

\subsubsection{Knowledge into Action Challenges}

Over the last decade there has been a convergence of agreement on what constitutes central challenges of sustainable development, essentially an agenda of priority areas (Table 4). These begin with Dr. Brundtland and the World Commission on Environment and Development, which identified six challenges for sustainable development: population and human resources, food security, species and ecosystems, energy, industry, and urban (WCED 1987). The NAS-BSD grouped two together and reduced these challenges to five (NAS-BSD 1999). Four of these were kept by the Secretary-General of the UN as an achievable agenda of the 2002 Johannesburg successor conference to Rio, and to which he added water, while dropping population (Annan 2002). My own Reader keeps all of these but expands the agenda to specifically include three grand challenges of sustainable development: poverty, climate change, and peace and security (Kates 2010).

Table 4. Knowledge into action: Global agendas. An agenda of priority areas or central challenges of sustainable development can be constructed from major documents beginning with Our Common Future from the World Commission on Environment and Development (WCED 1987), Our Common Journey from the NAS-BSD (1999), the Achievable Agenda of the Secretary-General of the UN (Annan 2002), and the Reader on Sustainability Science and Technology (Kates 2010).

\begin{tabular}{|c|c|c|c|}
\hline WCED 1987 & NAS-BSD 1999 & Annan 2002 & Kates 2010 \\
\hline Our Common Future & $\begin{array}{l}\text { Our Common } \\
\text { Journey }\end{array}$ & $\begin{array}{l}\text { Achievable } \\
\text { Agenda }\end{array}$ & $\begin{array}{c}\text { Sustainability Science } \\
\text { Reader }\end{array}$ \\
\hline $\begin{array}{c}\text { Population \& Human } \\
\text { Resources }\end{array}$ & $\begin{array}{c}\text { Human } \\
\text { Population }\end{array}$ & & Population \\
\hline & & Health & Health \& Well-being \\
\hline Food Security & Agriculture & Agriculture & $\begin{array}{c}\text { Agriculture \& Food } \\
\text { Security }\end{array}$ \\
\hline Species/Ecosystems & Living Resources & Biodiversity & $\begin{array}{c}\text { Biodiversity } \\
\text { Ecosystem Services }\end{array}$ \\
\hline Energy & $\begin{array}{l}\text { Energy } \\
\text { Industry }\end{array}$ & Energy & $\begin{array}{c}\text { Energy } \\
\text { Materials }\end{array}$ \\
\hline \multicolumn{4}{|l|}{ Industry } \\
\hline \multirow[t]{5}{*}{ Urban } & Cities & & Urban Growth \\
\hline & & Water & Water \& Sanitation \\
\hline & & & Poverty \\
\hline & & & Climate Change \\
\hline & & & Peace/Security \\
\hline
\end{tabular}


It is not clear how this set of challenges will emerge in 2012 when the United Nations again convenes a world conference in Rio. From the preliminary documentation (United Nations Preparatory Committee 2010), there will be a review of progress, which will probably touch on many of these challenges. But the themes of Rio are not on challenges, but on two means of addressing them specifically, economic mechanisms labeled collectively as the "green economy" and the complex of institutions addressing aspects of sustainable development.

\subsubsection{Acting on What We Already Know}

As noted in Table 4, we have had a consistent agenda of sustainability challenges and problems for two decades. Thus, sustainability science does not start from a blank slate; indeed, we already know ways of moving to a sustainability transition over the next two generations. For example, we know how to reduce the expected 9 billion population by as much as ten percent through increasing current trends in fertility reduction that meet unmet contraceptive needs, educate women, and delay marriage. Africa can produce much more food just by increasing its use of fertilizer. We can double the rate of improvement in energy intensity using technologies and behaviors that are readily available. Rapidly growing cities of developing countries can work efficiently, provide housing and employment, and become increasingly green. And we have learned much in how to restore degraded ecosystems. In the last decade, some progress has been made in all of these directions but in none have these been sufficient to overcome counter trends such as growth in fossil fuel use or unplanned expansion of existing cities.

There is also the process of localization. The challenges of sustainable development are placebased and sustainability scientists need to join hands with practitioners from local communities, industry, government, and civil society to address their specifics. This is beginning to happen, but still with few examples of solutions offered or problems solved. Thus the growing body of research may at best be only slowly yielding solutions for important global and local problems in the priorities for action in population, settlements, agriculture, energy and materials, and living resources identified in the NAS report (NAS-BSD 1999). In all of these, progress has been slow in this first decade of action. Finally, and perhaps most important, is the need to overcome the normal penchant to emphasize current uncertainty, and thus, the need to do more research, and to fail to acknowledge how much is already known about the crucial needs for a sustainability transition.

\subsubsection{Maine Sustainability Solutions Initiative}

Thus sustainability scientists are better at research than in finding and implementing solutions to local and regional sustainability problems. A major initiative is underway in my state of Maine to go beyond research and address Maine's sustainability problems and opportunities. It is a fiveyear effort funded jointly by the State and the EPSCoR program of the National Science Foundation and currently involves ten institutions of higher education in the state. The sustainability problems being addressed are those posed by the convergence of four important and long-term trends of landscape change. There is major change in forest resource management (87\% of Maine lands that are in forest) moving from paper company ownership to diverse ownership and development. In the south of the state, there is significant new urbanization. Climate change has already affected the state and will increase in the future. Renewable energy, particularly in hydropower, biofuels, and wind, may make the state a significant exporter of 
energy. In the major state research institutions, there is a current portfolio of 23 projects focusing on problems and needed solutions where these trends intersect. But there is also research on the research, addressing the efficacy of organizational innovations that facilitate interdisciplinary effort. Three other projects study the process of how to move knowledge into action.

Some of the problems with this large research program mirror problems identified at global scale, such as the bias to environmental problems in the current research portfolio. Academic researchers also have difficulty addressing big problems in their local expression and identifying and finding solutions. Most begin with what they already study and have difficulty to move beyond what they know to address bigger questions or to integrate their work with others. The project recognizes these problems, and some progress is being made in dealing with all of them.

\section{From the Unity of Nature to Sustainability Science}

Having reviewed both the ideas and practice of sustainability science, we can return to the opening theme of the paper in the form of a yet unborn sustainability scientist, Alexis V. Humble.

She too has a dream:

In a few hours we launch from Cape Canaveral the first of the next generation of Sustainability Earth Observation Satellites (SEOS). We shall collect full spectrum data on populations of people, plants, and places; the atmosphere and oceans; the movements of energy, materials, and information; of warfare and welfare; and of environment and development. But that's not the main purpose of our science. We shall try to find out how the forces of nature and society interact upon one another and how the geographic environment and the complex system of life can sustain itself. In other words, we must find out about the unity of nature that we humans are both part of and apart from. 


\section{References}

Buizer, J. (2011). Personal communication, e-mail, 1/24/2011.

Burton, I, R. W. Kates, and G. F. White. (1978). The Environment as Hazard. Second ed. New York: The Guilford Press, 1993.

Clark, W. C. (2007). Sustainability science: A room of its own. Proceedings of the National Academy of Sciences 104: 1737.

Clark, W. C., and S. A. Levin. (2010). Toward a Science of Sustainability. Report of Conference Toward a Science of Sustainability, 2009, at Airlie Center, Warrenton, Virginia.

Daily, G. C., et al. (1997). Ecosystem services: Benefits supplied to human societies by natural ecosystems. Issues in Ecology 2: 1-18.

European Commission, Research Directorate General for Environment. (2009). Report from the Workshop on Sustainability Science, Brussels, 28 October 2009. RTD/I.2/ND/VG/cm D(2009)576942. Brussels: EC. Available from http://ec.europa.eu/.../report_workshop_sustainability_science_october_2009.pdf.

Interacademy Panel on International Issues. (2000). Transition to Sustainability in the 21st Century. Trieste: Interacademy Panel. Available from http://www.interacademies.net/?id=3568.

International Council for Science. (2002). Science and Technology for Sustainable Development: Report from the Synthesis Meeting Sponsored by the Initiative on Science and Technology for Sustainability. TWAS and ICSU Series on Science for Sustainable Development 9. Paris: ICSU.

Jäger, J. (2009). Sustainability Science in Europe. (Background paper prepared for European Commission's DG for Research). Available from http://ec.europa.eu/research/sd/pdf/workshop2009/background_paper_sust_science_workshop_october_2009.pdf.

Kates, R. W., et al. (2001). Sustainability science. Science 292: 641-642.

Kates, R. W., ed. (2010). Readings in Sustainability Science and Technology. CID Working Paper No. 213. Center for International Development, Harvard University. Cambridge, MA: Harvard University, December 2010. (Also available at http://www.hks.harvard.edu/centers/cid/publications/faculty-working-papers/cid-working-paperno.-213.)

Komiyama, H., K. Takeuchi, H. Shiroyama, and T. Mino, eds. (2010). Sustainability Science: A Multidisciplinary Approach. Washington, DC: Brookings Institution Press. 
Lotze-Campen, H. (2007). Review of Experience with Existing Models and their Suitability for Integrated Sustainability Assessment (ISA), MATISSE Working Paper No. 16. Available at http://www.matisse-project.net.

Lotze-Campen, H. (2008). The role of modelling tools in Integrated Sustainability Assessment (ISA). Int. J. Innovation and Sustainable Development 3 (1-2): 70-92.

Matson, P. A. (2009). The sustainability transition. Issues in Science and Technology Summer. Available at http://www.issues.org/25.4/matson.html\#.

Marsh, G. P. (1965) [1864]. Man and Nature: Or Physical Geography as Modified by Human Action. Cambridge, Massachusetts: Belknap Press of Harvard University Press.

National Research Council, Board on Sustainable Development. (1999). Our Common Journey: A Transition Toward Sustainability. Washington, DC: National Academy Press.

Nicolson, M. (1995). Historical Introduction In Personal Narrative of a Journey to the Equinoctial Regions of the New Continent by Alexander von Humboldt. London: Penguin Books.

PNAS. (2010). http://www.pnas.org/site/misc/sustainability.shtml.

Raskin, P., et al. (2002). Great Transition: The Promise and Lure of the Times Ahead. Boston: Stockholm Environment Institute.

Stokes, D. E. (1997). Pasteur's Quadrant : Basic Science and Technological Innovation. Washington, DC: Brookings Institution Press.

Thomas, W. L., Jr., ed. (1956). Man's Role in Changing the Face of the Earth. Chicago: University of Chicago Press.

Turner, B. L., II, et al., eds. (1990). The Earth as Transformed by Human Action. Cambridge: Cambridge University Press and Clark University.

United Nations, Preparatory Committee for the United Nations Conference on Sustainable Development. (2010). Report of the Secretary-General: Progress to date and remaining gaps in the implementation of the outcomes of the major summits in the area of sustainable development, as well as an analysis of the themes of the Conference. A/CONF.216/PC/2. New York: United Nations.

Vernadsky, V. I. (1998). Biosphere: Complete Annotated Edition. New York: Copernicus Books (Springer Verlag).

World Commission on Environment and Development (WCED). (1987). Our Common Future. New York: Oxford University Press. 